\title{
Actual evapotranspiration and crop coefficient of sweet orange during the initial development phase in the Rio Largo region, Alagoas
}

\section{Ricardo Barros Silva ${ }^{*}$ iD José Leonaldo de Souza ${ }^{2}$ Ricardo Araújo Ferreira Júnior ${ }^{2}$ Marcos Alex dos Santos ${ }^{2}$ Renan Cantalice de Souza ${ }^{3}$ Wellington Manoel dos Santos ${ }^{1}$}

\author{
${ }^{1}$ Programa de Pós-graduação em Agronomia, Universidade Federal de Alagoas (UFAL), 57100-000, Rio Largo, AL, Brasil. E-mail: \\ ricardoufa12010@gmail.com. *Corresponding author. \\ ${ }^{2}$ Laboratório de Irrigação e Agrometeorologia (LIA), Centro de Ciências Agrárias (CECA), Universidade Federal de Alagoas (UFAL), Rio \\ Largo, AL, Brasil. \\ ${ }^{3}$ Laboratório de Manejo de Plantas Daninhas, Centro de Ciências Agrárias (CECA), Universidade Federal de Alagoas (UFAL), Rio Largo, \\ AL, Brasil.
}

\begin{abstract}
Determining actual crop evapotranspiration (ETa) is paramount for irrigation management. The principal measurement methods and physical models generally require crop and weather data that are not readily available. We determined the crop coefficient (Kc) of sweet oranges during the initial development stage and evaluated the performance of the Poulovassilis semi-empirical model coupled with a simple soil water balance for estimating the ETa. The ETa was inferred from the variation in the soil water content over time, measured by time-domain reflectometry. In the Poulovassilis model, the ETa is obtained by multiplying the crop evapotranspiration (ETc) by an adjustment coefficient (ca), which accounts for a reduction in the evapotranspiration caused by soil water depletion. Soil water storage was obtained using the daily and 10-day soil water balances, computed by considering inputs and outputs of water from the system. The empirical parameter, ca, was determined using inverse modeling. The optimal ca value obtained through inverse modeling was 0.05 and 0.03 for the daily and 10-day soil water balances, respectively. The model performed better for the daily soil water balance than the 10-day balance, with performance comparable with the other ETa models. Average Kc during the sweet orange initial crop stage was 0.85 .

Key words: Citrus sinensis (L.) Osbeck, evapotranspiration reduction, water balance.
\end{abstract}

Evapotranspiração real e coeficiente da cultura da laranja lima durante a fase inicial de desenvolvimento na região de Rio Largo, Alagoas

RESUMO: A determinação da evapotranspiração real da cultura (ETa) é importante para o manejo da irrigação. Os principais métodos e modelos fisicos de estimativa da ETa requerem dados que não são facilmente disponíveis. Neste trabalho, obteve-se o coeficiente da cultura (Kc) da laranja lima na fase inicial de desenvolvimento e avaliou-se o desempenho do modelo semi-empírico de Poulovassilis acoplado a um balanço hídrico simplificado na estimativa da ETa. A ETa (medida) foi obtida a partir da variação temporal do conteúdo de água no solo, obtida através da reflectometria no domínio do tempo (TDR). O modelo de POULOVASSILIS et al. (2001) assume que a redução da evapotranspiração da cultura é expressa por uma função exponencial do armazenamento de água do solo e por um coeficiente de ajuste empírico (ca). O armazenamento de água do solo foi obtido através do balanço hídrico (BH), diário e decendial, contabilizando as entradas e saídas de água do sistema. O parâmetro empírico ca foi obtido por modelagem inversa. O valor ótimo de ca obtido por modelagem inversa 0,05 para o BH diário e 0,03 para o BH decendial. O modelo apresentou melhor desempenho para o BH diário, comparável a outros modelos de estimativa da ETa. O Kc médio para fase inicial da laranja lima foi igual a 0,85.

Palavras-chave: Citrus sinensis L. Osbeck, redução da evapotranspiração, balanço hídrico.

\section{INTRODUCTION}

Oranges are one of the most widely consumed fruits worldwide, either "in natura" or through derivatives, generating employment and income in the producing regions. According to the IBGE (2018), Brazil was the world's largest orange producing country in 2017 , with a harvest of 17.5 million tons that corresponded to $23.8 \%$ of the global production and a yield of $27.6 \mathrm{t} \mathrm{ha}^{-1}$. Within Brazil, São Paulo is the largest producer (13.35 million tons), whereas Alagoas is the eighth largest producer (156 thousand tons), with a yield of $14.75 \mathrm{tha}^{-1}$.

The climatic conditions of the coastal table land region of Alagoas (which is unlike the other Northeastern micro-regions) favor orange 
cultivation. Considering crop's climatic requirements (temperatures between 13 and $35^{\circ} \mathrm{C}$, annual rainfall between 600-1200 mm) (REUTHER, 1973; BEN MECHLIA \& CARROLL, 1989), the region provides an adequate thermal availability (annual temperatures between 19 and $31^{\circ} \mathrm{C}$ ) and an average annual rainfall of $1818 \mathrm{~mm}$. However, the rainfall distribution in this region is seasonal, with a dry season occurring during part of the year, which renders crop irrigation necessary (SOUZA et al., 2005).

Actual crop evapotranspiration (ETa), which occurs on a vegetated surface, regardless of the development stage or soil moisture conditions, and without any boundary conditions is one of the main variables assisting rational water management in agriculture. Complexity and operational costs of the direct or indirect measurement methods for Eta favor a more common usage of estimation models (BRUTSAERT, 1982; RANA \& KATERJI, 2000). Eta estimation models can be either physical, such as Penman-Monteith's (MONTEITH, 1981) and Shuttleworth-Wallace's (SHUTTLEWORTH \& WALLACE, 1985), or empirical/semi-empirical (ALLEN et al., 1998; POULOVASSILIS et al., 2001).In the latter, ETa values are derived from the concept of crop evapotranspiration (ETc) evapotranspiration that occurs in cultivation areas, under optimal management conditions, without soil moisture restrictions (ALLEN et al., 1998). Generally, ETc is estimated by the crop coefficient proposed by ALLEN et al. (1998), which consists of multiplying the reference evapotranspiration $\left(\mathrm{ET}_{0}\right)$ evapotranspiration from a hypothetical grass with a height of $0.12 \mathrm{~m}$, albedo of 0.23 , and a fixed surface resistance of $70 \mathrm{~m} \mathrm{~s}^{-1}$ - by the crop coefficient $(\mathrm{Kc})$ that is dependent upon the crop development stage.

Semi-empirical methods (e.g., FEDDES et al., 1978; ALLEN et al., 1998; POULOVASSILIS et al., 2001) estimate the ETa by multiplying the ETc by a reduction factor (a dimensional, varying between 0 and 1), to account for the reduction on ETc due to soil hydraulic limiting conditions. Therefore, these models differ by the mathematical expression used for the reduction factor, the soil routine employed for maintaining the water balance, or the partitioning of evapotranspiration into transpiration and evaporation. Compared with other models (e.g., FEDDES et al., 1978; ALLEN et al., 1998), the model proposed in POULOVASSILIS et al. (2001) is simpler and requires only one input empirical parameter (responsible for the exponential decrease of the ETc), which is a function of soil water storage. Although, this model was satisfactory in estimating the ETa of corn, wheat, and cotton (POULOVASSILIS et al., 2001), its performance for other crops; e.g., fruit crops, such as sweet orange needs evaluation. Moreover, the empirical parameter for the reduction curve varies with the soil type, crop, and atmospheric demand, thus requiring an adjustment for these conditions.

Semi-empirical approach to estimate the ETa requires the determination of $\mathrm{ET}_{0}$ and the crop coefficient. The former is commonly measured or estimated in meteorological stations. The latter, however, varies with crop type and development stage(ALLEN et al., 1998). Furthermore, for citrus species, experimental results show that $\mathrm{Kc}$ may vary with soil and climatic conditions, owing to the higher inner resistances to water transport (MARIN \& ANGELOCCI, 2011). The Kc values for citrus for the mid-seasonstageare widely reported in literature (e.g., SEPASKHAH et al., 1995; MORAES et al., 2015), but Kc data for the initial development stage are still scarce. Therefore, Kc values during the initial stage of citrus development need to be evaluated for each local condition.

The objective of this paper was to evaluate the POULOVASSILIS et al. (2001) model in estimating the ETa, coupled with a simple soil water balance model,during the initial stage of sweet orange tree growth in the Rio Largo region, in the coastal tablelands of Alagoas. Additionally, the $\mathrm{Kc}$ was determined for the initial crop growth stage.

\section{MATERIALS AND METHODS}

The experiment was carried out in an orchard located in the experimental area of the Agricultural Sciences Center of the Federal University of Alagoas (CECA-UFAL), in the coastal table land region, municipality of Rio Largo, Alagoas, Brazil (geodesic coordinates: latitude 9 ${ }^{\circ} 27^{\prime} 58.7^{\prime}$ 'S, longitude $35^{\circ} 49^{\prime} 47.2^{\prime \prime} \mathrm{W}$, and altitude $127 \mathrm{~m}$ ). According to the Thornthwaite classification (THORNTHWAITE \& MATHER, 1955), the climate of the region is characterized as humid, megathermal, with moderate water deficiency in the summer and substantial water excess in the winter. The average annual rainfall is $1818 \mathrm{~mm}$, the air temperature varies between 19.3 ${ }^{\circ} \mathrm{C}$ (August) and $31.7^{\circ} \mathrm{C}$ (January), with an annual average of $25.4{ }^{\circ} \mathrm{C}$, and the average monthly relative humidity is above $70 \%$ (SOUZA et al., 2005). The soil of the region is classified as a cohesive yellow clay Latosol, with a field capacity $\left(\Theta_{\mathrm{FC}}\right)$ of $0.232 \mathrm{~m}^{3}$ $\mathrm{m}^{-3}$, permanent wilting point $\left(\Theta_{\mathrm{PWP}}\right)$ of $0.139 \mathrm{~m}^{3} \mathrm{~m}^{-3}$, soil density of $1.50 \mathrm{~g} \mathrm{~m}^{-3}$, total porosity of $0.423 \mathrm{~m}^{3}$ $\mathrm{m}^{-3}$, and basic infiltration rate of $52 \mathrm{~mm} \mathrm{~h}^{-1}$. 
Sweet orange plants grafted on lemon trees were transplanted on April 8, 2016, in a 1904 $\mathrm{m}^{2}$ plot arranged into 7 cultivation lines with 16 plants each, totaling 112 plants (spaced $4 \times 4 \mathrm{~m}$ ). The experimental evaluation occurred between August 2016 and March 2017. Formation pruning was carried out in January 2017. During the experimental period, meteorological data were obtained from the CECA - UFAL automatic agrometeorological station. The $\mathrm{ET}_{0}$ was obtained using the PenmanMonteith-FAO method (ALLEN et al., 1998).

The drip irrigation system was adopted in the orchard, using self-compensating drippers with a flow of $8 \mathrm{~L} \mathrm{~h}^{-1}$. A wet bulb area of $0.65 \mathrm{~m}^{2}$ was applied to convert the volume of irrigated water (L) into water in the soil ( $\mathrm{mm})$, the value for which was determined by testing values for the dimension of the wet area that were consistent with moisture readings recorded by the field sensors. Irrigation shift was fixed at 2-day intervals, based on the $\mathrm{ET}_{0}$. The soil water content $\left(\Theta, \mathrm{m}^{3} \mathrm{~m}^{-3}\right)$ was monitored using a TDR apparatus (Water Content Reflectometers Model CS616, Campbell Scientific) by horizontally installing two probes in the $0-30$ $\mathrm{cm}$ depth layer of the soil adjacent to two evaluated plants. The effective depth of the crop root system was assumed to be $0.3 \mathrm{~m}$, considering that the orchard was composed of young plants. The $\Theta$ data obtained by the TDR apparatus were adjusted to a second-degree polynomial equation, relating the $\Theta$ and dielectric constant obtained by the TDR.

The ET on rainfall-free days was obtained from the variation in the soil water storage $(W, \mathrm{~mm})$ (RANA \& KATERJI, 2000): $\mathrm{ET}=\Delta \mathrm{W}$

where $W$ is $1000 \Theta Z r$, with $Z r(0.3 \mathrm{~m})$ being the effective depth of the root system and 1000 being the unit conversion factor (from $\mathrm{m}$ to $\mathrm{mm}$ ). When $\Theta$ was at field capacity, the ET was equal to ETc. For $\Theta$ below the field capacity, the ET corresponded to the observed ET a (determined by the moisture variation obtained by TDR). The ETc values obtained from Eq. 1 allowed the determination of the crop coefficient $(\mathrm{Kc})$, defined as $\mathrm{Kc}=\mathrm{ETc} / \mathrm{ET}_{0}$. These $\mathrm{Kc}$ values take into the account the wet area adjustment factor, since Kc was determined with ETc values (Eq. 1) that were measured in the wet area.

The ETa was estimated using the POULOVASSILIS et al. (2001) model (herein after referred as Poulovassilis model), which is defined by the following equation:

$$
E T \mathrm{a}=E T c \exp \left\lceil\frac{c a\left(W-W_{f c}\right)}{W-W_{w b}}\right\rceil
$$

where $W_{f c}(\mathrm{~mm})$ is the water stored in the soil at field capacity, $W_{w p}(\mathrm{~mm})$ is the water stored in the soil at the permanent wilting point, and $\mathrm{ca}(-)$ is an adjustment coefficient. The $c a$ parameter was obtained using inverse modeling, minimizing the following objective function:

$$
\phi(c a)=\sum_{l}^{N}=\left[E T a_{j}^{*}-E T a_{i}(c a)\right]^{2}
$$

where $\Phi(c a)$ is the objective function to be minimized, $E T a_{j}^{*}$ are the observed ETa values (Eq. 1), ETa $(\mathrm{ca})$ are the ETa values estimated by the Poulovassilis model coupled with the water balance, and $c a$ is the parameter to be optimized. Function minimization was achieved through the non-linear generalized reduced gradient (GRG) method (WOLFE, 1963) using the Microsoft Excel solver tool.

Soil water storage was obtained through the daily and 10-day water balances (WB), counting the system water inputs and outputs, according to LHOMME et al. (1984):

$\mathrm{W}_{j}=\mathrm{W}_{j-1}+\mathrm{P}_{j}+\mathrm{I}_{j}-\mathrm{ETa}_{j}-\mathrm{D}_{j}$

where $P_{j}$ corresponds to the rainfall $(\mathrm{mm}), I_{j}(\mathrm{~mm})$ to the irrigation, ET aj $\left(\mathrm{mm}\right.$ day $\left.^{-1}\right)$ is the actual evapotranspiration estimated by the Poulovassilis model, and $D(\mathrm{~mm})$ is the drainage, obtained from the equation:

$$
D_{J}=\left|\begin{array}{ll}
P E_{j}-C R_{J}-E T a, & \text { if } P E_{j}-E T a_{j}>C R_{J} \\
0 & \text {,if } P E_{J}-E T a \leq C R_{j}
\end{array}\right|
$$

where $C R$ is the actual water storage capacity of the period (mm), obtained from $W_{f c}-W_{j-1}$. The subscript $j$ of Eqs. 4 and 5 indicates the day (or 10day period) in which each variable was determined. The storage obtained by Eq. 4 was compared with the TDR-measured values.

The WB was started on a given day (or 10day period), which occurred after a series of rainy days, where the soil water storage $\left(W_{j}\right)$ was at field capacity. Thereby, it was possible to solve Eqs. 2 and 4, as the soil moisture at the beginning of the WB was known.

The performance of the model was evaluated by comparing the estimated Eta values (for daily and 10-day WB periods) with the measured Eta (obtained using Eq. 2) using the following statistical indices, as suggested by LEGATES and MCCABE JR. (1999): coefficient of determination $\left(\mathrm{r}^{2}\right)$, data dispersion around the 1:1 straight line and its slope, Willmott's index of agreement (d), NashSutcliffe efficiency coefficient (E), and root mean square error (RMSE).

\section{RESULTS AND DISCUSSION}

The optimal $c a$ values, computed by minimizing the objective function $\Phi$ (ca) (Eq. 3), 
were 0.05 and 0.03 for the daily and 10-day WB periods, respectively. These are well below the values suggested by Poulovassilis for cotton, maize, and wheat crops ( $c a=0.2)$. The $c a$ parameter of the Poulovassilis model is related to the shape of the evapotranspiration reduction curve. For lower $c a$ values, such as those obtained herein ( $\mathrm{ca}=0.03$ and 0.05$)$, the reduction curve is $\mathrm{ETa} / \mathrm{ETc}$ vs $W$ is moderately reduced as $W$ decreases (POULOVASSILIS et al., 2001). Low $c a$ values are associated with low atmospheric demand for water, soils with high hydraulic conductivity, and/or plants that are more tolerant to water stress (POULOVASSILIS et al., 2001). Some experimental studies (e.g., CONSOLI et al., 2014; GASQUE et al., 2016) have indicated that orange crops have a tolerance to water stress (supporting pressure head values between -1.7 and 2.0 MPa). However, these studies preclude any inference on the shape of the evapotranspiration reduction curve and; therefore, one cannot infer whether the low $c a$ values computed here are characteristic of sweet orange or caused by the effects of both the soil and climatic conditions. One way to investigate the characteristics influencing the $c a$ could be to compare results of the Poulovassilis model to physical model simulations (after being calibrated for the crop), similar to modeling exercise by Santos et al. (2017). However, this is beyond the scope of this paper.

Although, the sensitivity analysis (Figure 1) indicated that the optimization was important to improve the Eta estimated by the Poulovassilis model, coupled with the simple WB, it was also observed that the Poulovassilis model is not very sensitive to the $c a$ parameter at $c a$ values around 0.2. For example, if one uses a $c a$ of 0.2 instead of 0.05 (for the daily WB), the objective function increases by just $7.5 \%$. Although, this sensitivity also depends upon the accuracy of the WBs used, it should be noted that the results suggested that tabled values for certain groups of crops, parameterized for some soil classes and atmospheric demands, are enough to apply the Poulovassilis model without greatly influencing its performance.

The model performance, concerning the estimation of the Eta for the daily and 10-day periods, is indicated by the statistical indices of table 1 and figure 2. In general, the daily WB model performed at a better level than did the 10-day WB model. The slope coefficient of line 1:1 of Figure 2 ( $b$ and $d$ ) indicated that, in general, the model underestimated the Eta during the evaluation period, and more so in the 10day WB model. Conversely, the soil water storage was

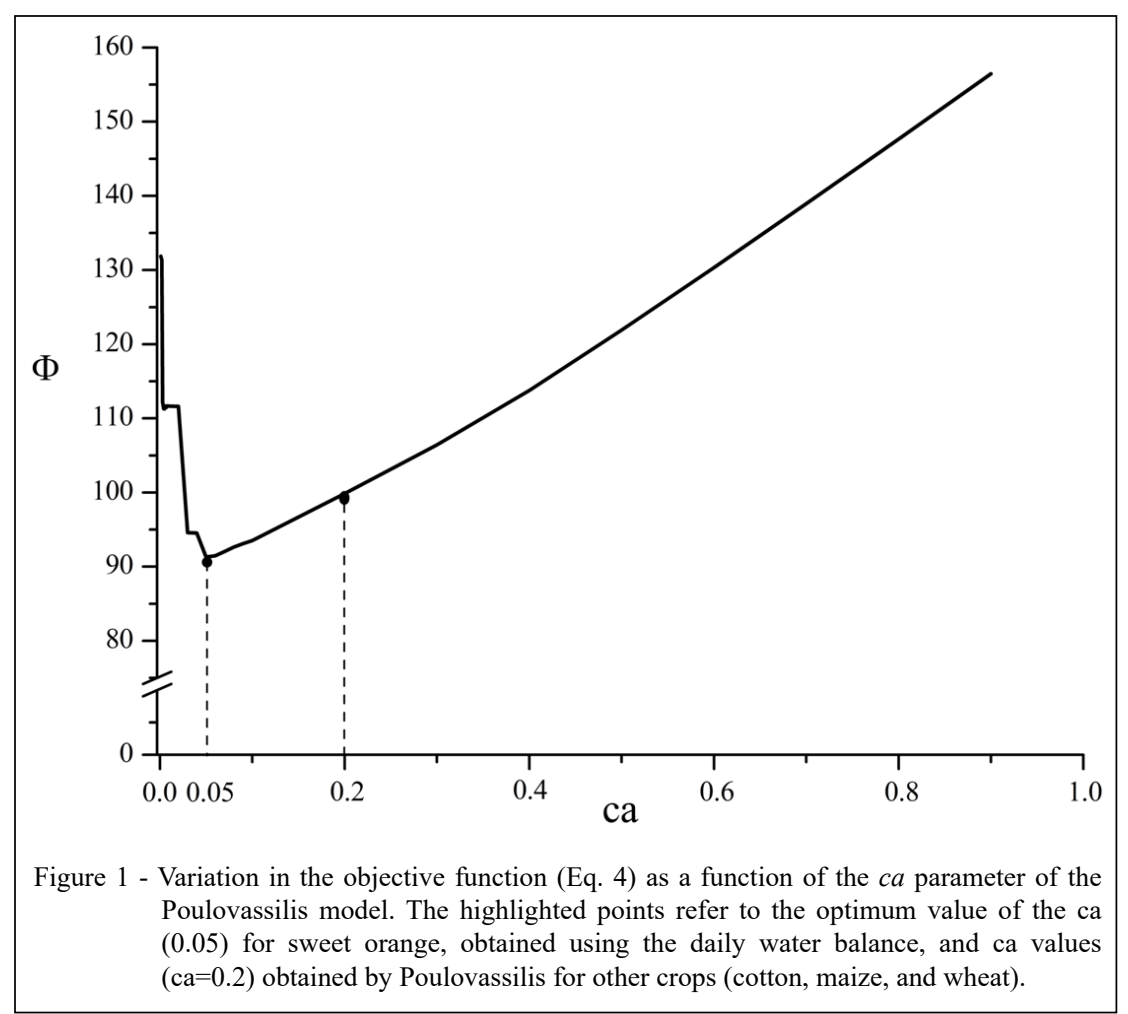

Ciência Rural, v.49, n.6, 2019. 
Table 1 - Statistical indices for the comparison between the measured and estimated Eta for the daily and 10days water balances. $c a$ is the adjustment coefficient of POULOVASSILIS et al. (2001) model obtained by optimization $r^{2}$ is the coefficient of determination, $d$ is Willmott's index of agreement, $E$ is the Nash-Sutcliffe model efficiency coefficient, and RMSE is the root mean square error.

\begin{tabular}{lccccc}
\hline $\begin{array}{l}\text { Water } \\
\text { Balance }\end{array}$ & $\mathrm{Ca}$ & $\mathrm{r}^{2}$ & $\mathrm{~d}$ & $\mathrm{E}$ & $\mathrm{RMSE}$ \\
\hline Daily & 0.05 & 0.79 & 0.94 & 0.74 & 1.30 \\
10-day & 0.03 & 0.69 & 0.91 & 0.49 & 12.52 \\
\hline
\end{tabular}

overestimated both in the daily and 10-day scales and may be associated with the underestimation of the ETa.

The RMSE corresponds to the mean error of the estimates, being equal to $1.3 \mathrm{~mm} \mathrm{~d}^{-1}$ and 1.25 $\mathrm{mm} \mathrm{d}^{-1}$ (mean daily value) for the daily and 10-day WBs, respectively. These values are comparable to values generated by other ETa estimation models (ERRAKI et al., 2009; RAN et al., 2017). The relatively highr $^{2}$ values indicate the precision of the model, while the values of $E$ are related to accuracy. The $E$ values of 0.74 and 0.49 for the daily and 10-day WBs, respectively, are more aligned with the performance of the model than with the index $d(>0.9)$, regarding the dispersion of the values around the 1:1 line and the RMSE values. Interpretation errors of the indices $d$ and $E$ are discussed in the study of LEGATES and MCCABE JR. (1999).

The average $\mathrm{Kc}$ for sweet orange during the initial growth phase was equal to 0.85 (Table 2). Similar values were obtained by other authors for this phase: 0.85 (DOORENBOS \& PRUITT, 1977) and 1.0 (PEREIRA \& ALLEN, 1997). It is important to highlight that the Kc of citrus species, as observed by MARIN and ANGELOCCI (2011), may vary according to atmospheric demand. Under moderate to
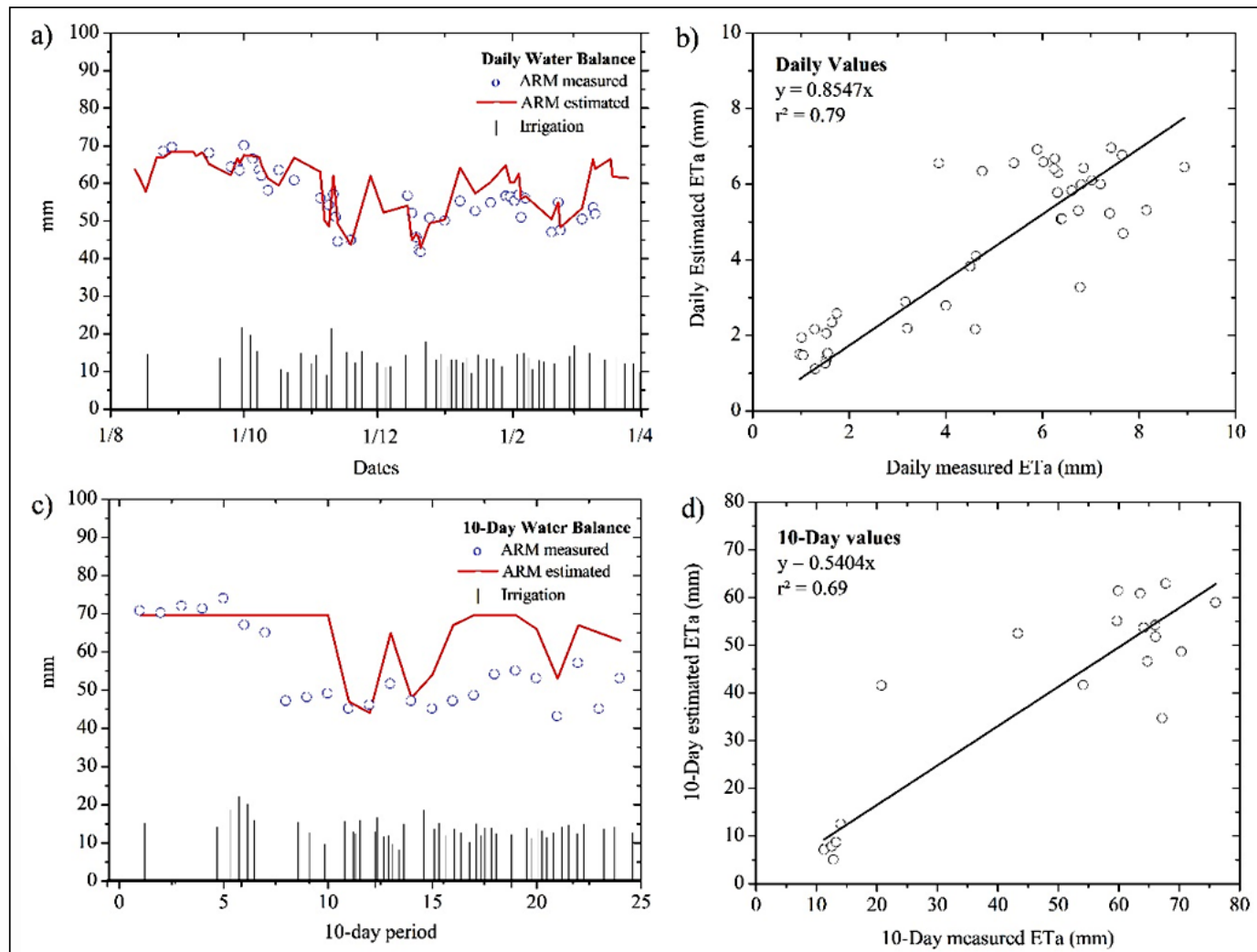

Figure 2 - Soil water content (W), measured by TDR and estimated using the daily and 10-day water balances (mm) during the experimental evaluation period, the applied irrigation blade $(\mathrm{mm})$, and the determination coefficient $\left(\mathrm{r}^{2}\right)$ with its respective $1: 1$ straight line. 
Table 2 - Monthly values for the crop coefficient (Kc) during the experimental evaluation period, along with the average for the first year of sweet orange cultivation.

\begin{tabular}{lc}
\hline Month & Monthly Crop Coefficient (Kc) \\
\hline August & 0.30 \\
September & 0.31 \\
\hline October & 0.41 \\
\hline November & 1.28 \\
\hline December & 1.18 \\
\hline January & 1.12 \\
\hline February & 1.22 \\
\hline March & 1.05 \\
\hline Final Average & 0.85 \\
\hline
\end{tabular}

high atmospheric demand conditions, the high inner resistance to water transport (characteristic of citrus species) limits the ETc, decreasing the Kc value - i.e., in places with a high $\mathrm{ET}_{0}$, there is a tendency to obtain lower Kc values. In the period between August and October, the mean $\mathrm{ET}_{0}$ value was $4.46( \pm 0.86) \mathrm{mm}$ day $^{-1}$, whereas between November and March it was $5.13( \pm 0.77) \mathrm{mm}$ day $^{-1}$. These high $\mathrm{ET}_{0}$ values may have contributed to the relatively low value of $\mathrm{Kc}$.

\section{CONCLUSION}

The semi-empirical model proposed by Poulovassilis, coupled with a simple water balance, estimated satisfactorily the actual evapotranspiration of sweet oranges during the initial crop growth stage, with values of the $c a$ parameter equal to 0.05 (for the daily water balance) and 0.03 (for the 10 day water balance).

The crop coefficient obtained for sweet orange during the initial crop growth stage in the coastal table land region of Alagoas was 0.85 .

\section{ACKNOWLEDGEMENTS}

To the Foundation for Research Support of the State of Alagoas (FAPEAL) and to the National Council for Scientific and Technological Development (CNPq).

\section{DECLARATION OF CONFLICT OF INTERESTS}

The authors declare no conflict of interest. The founding sponsors had no role in the design of the study; in the collection, analyses, or interpretation of data; in the writing of the manuscript, and in the decision to publish the results.

\section{CONTRIBUTIONS OF AUTHORS}

The authors contributed equally to this manuscript.

\section{REFERENCES}

ALLEN, R.G. et al. Crop evapotranspiration: guidelines for computing crop requirements. Roma: Food and Agriculture Organization of the United Nations (FAO), 1998. 328p. (Irrigation and drainage paper, 56).

BEN MECHLIA, N.; CARROLL, J.J. Agroclimatic modeling for simulation of phenology, yield and quality of crop production. I. Citrus response formulation. International Journal of Biometeorology, Berlin, v.33, p.36-51, 1989. Available from: $<$ https://link.springer.com/article/10.1007\%2FBF01045896>. Accessed: Feb. 10, 2019. doi: 10.1007/BF01045896.

BRUTSAERT, W. Evaporation into the atmosphere: theory, history and applications. Dordrecht, Kluwer Academic Publishers, 1982. 302p.

CONSOLI, S. et al. Sustainable management of limited water resources in a young orange orchard. Agricultural Water Management, v.132, p.60-68, 2014. Available from: $<$ https://www. sciencedirect.com/science/article/pii/S037837741300276X>. Accessed: Aug. 20, 2018. doi: 10.1016/j.agwat.2013.10.006.

DOORENBOS, J.; PRUITT, W.O. Crop water requirements. Roma: Organização das Nações Unidas para Alimentação e Agricultura (FAO), 1977. 144p. (Irrigation and Drainage Paper, 24).

ER-RAKI, S. et al. Citrus orchard evapotranspiration: comparison between eddy covariance measurements and the FAO-56 approach estimates. Plant Biosystems, v.143, p.201208, 2009. Available from: <https://www.tandfonline.com/doi/ abs/10.1080/11263500802709897>. Accessed: Feb. 10, 2019. doi: $10.1080 / 11263500802709897$.

FEDDES, R.A. et al. Simulation of field water use and crop yield. New York: John Wiley \& Sons, 1978. 188p.

GASQUE, M. et al. Effects of long-term summer deficit irrigation on 'Navelina' citrus trees. Agricultural Water Management, v.169, p.140-147, 2016. Available from: <https://www.sciencedirect. com/science/article/pii/S0378377416300750>. Accessed: Aug. 15, 2018. doi: 10.1016/j.agwat.2016.02.028.

IBGE. Produção agrícola municipal. Available from: $<$ https:// sidra.ibge.gov.br/pesquisa/pam/tabelas>. Accessed: Dec. 18, 2018.

LEGATES, D.R.; MCCABE Jr., G.J. Evaluating the use of "goodness-of-fit" measures in hydrologic and hydroclimatic model validation. Water resources research, v.35, p.233-241, 1999. Available from: <https://agupubs.onlinelibrary.wiley.com/ doi/10.1029/1998WR900018>. Accessed: Aug. 20, 2018. doi: 10.1029/1998WR900018.

LHOMME, J.P. et al. Modelo matemático del balance hídrico. Turrialba, v.34, p.503-507, 1984.

MARIN, F.R.; ANGELOCCI, L.R. Irrigation requirements and transpirations coupling to the atmosphere of a citrus orchard in Southern Brazil. Agricultural Water Management, v.98, p.1091- 
1096, 2011. Available from: <https:/www.sciencedirect.com/ science/article/pii/S0378377411000357?via\%3Dihub>. Accessed: Aug. 23, 2018. doi: 10.1016/j.agwat.2011.02.002.

MONTEITH, J.L. Evaporation and surface temperature. Quarterly Journal Of The Royal Meteorological Society, v.107, p.1-27, 1981. Available from: <https://rmets.onlinelibrary.wiley.com/ doi/abs/10.1002/qj.49710745102>. Accessed: Feb. 12, 2019. doi: 10.1002/qj.49710745102.

MORAES, J.G. et al. Balanço hídrico e coeficiente de cultura da laranjeira 'Folha Murcha' no Noroeste Fluminense. Revista Ciência Agronômica, v.46, p.241-249, 2015. Available from: $<$ http://www.ccarevista.ufc.br/seer/index.php/ccarevista/article/ view/3154>. Accessed: Jul. 15, 2018. doi: 10.5935/18066690.20150003

PEREIRA, L.S.; ALLEN, R.G. Novas aproximações aos coeficientes culturais. Engenharia Agrícola, v.16, p.118-43, 1997.

POULOVASSILIS, A. et al. Semi-empirical approach for estimating actual evapotranspiration in Greece. Agricultural Water Management, v.51, p.143-152, 2001. Available from: <https://www.sciencedirect.com/science/article/pii/ S0378377401001214?via\%3Dihub>. Accessed: Feb. 02, 2018. doi: 10.1016/S0378-3774(01)00121-4.

RAN, H. et al. Performance of AquaCrop and SIMDualKc models in evapotranspiration partitioning on full and deficit irrigated maize for seed and production under plastic film-mulch in arid region of China. Agricultural Systems, v.151, p.20-32, 2017. Available from: <https://www.sciencedirect.com/science/ article/pii/S0308521X16307454>. Accessed: Feb. 10, 2019. doi: 10.1016/j.agsy.2016.11.001.

RANA, G.; KATERJI N. Measurement and estimation of actual evapotranspiration in the field under Mediterranean climate: a review. European Journal of Agronomy, v.13, p.125-153, 2000. Available from: <https://www.sciencedirect.com/science/article/
pii/S1161030100000708>. Accessed: Jul. 23, 2018. doi: 10.1016/j. renene.2004.09.013.

REUTHER, W. The citrus industry. California, University of California. 1973. 377p.

SANTOS, M. A. Benchmarking test of empirical root water uptake models. Hydrology Earth System Science, v.21, p.473493, 2017. Available from: <https://www.hydrol-earth-syst-sci. net/21/473/2017/>. Accessed: Feb. 07, 2019. doi: 10.5194/hess21-473-2017.

SEPASKHAH, A.R; KASHEFIPOUR, S.M. Evapotranspiration and crop coefficient of sweet lime under drip irrigation. Agricultural Water Management, v.27, p.331-340, 1995 Available from: <https://www.sciencedirect.com/science/ article/pii/0378377495011437>. Accessed: Jan. 23, 2019. doi: 10.1016/0378-3774(95)01143-7.

SOUZA, J.L. et al. Global solar radiation measurements in Maceió, Brazil. Renewable Energy, v.30, p.1203-1220, 2005. Available from: $<$ https://www.sciencedirect.com/science/article/ pii/S0960148104003842> Accessed: Jul. 20, 2018. doi: 10.1016/j. renene.2004.09.013.

SHUTTLEWORTH, W.J.; WALLACE, J.S. Evaporation from sparse crops-an energy combination theory. Quarterly Journal of the Royal Meteorological Society, v.111, p.839-855, 1985. Available from: <https://rmets.onlinelibrary.wiley.com/doi/ abs/10.1002/qj.49711146910>. Accessed: Feb. 14, 2019. doi: 10.1256/smsqj.46909.

THORNTHWAITE, C.W.; MATHER, J.R. The water balance Centerton, NJ: Drexel Institute of Technology - Laboratory of Climatology, 1955. 104p.

WOLFE, P. The Reduced Gradient Method. In: GRAVES, R.L.; WOLFE, P. Recent Advances in Mathematical Programming. New York. p.67-86, 1963. 